\title{
MÛSÂ CÂRULLAH BİGIYYFF EFENDİ VE İMAN ADLI MAKALESİ
}

\author{
Mûsâ Cârullah Bigiyef Master and His Article Titled Faith
}

\section{Süleyman ÇAM*}

Makale Bilgileri

$\begin{array}{ll}\text { Geliş Tarihi: } & 17.03 .2020 \\ \text { Kabul Tarihi: } & 26.11 .2020 \\ \text { Yayın Tarihi: } & 25.12 .2020\end{array}$

\begin{abstract}
Özet
Bu çalışmada, Osmanlının son dönemlerinde yaşayan Tatar ulemasından Mûsâ Cârullah Bigiyef Efendi'nin hayat, eserleri ve bazı teolojik görüşlerine yer verilmiştir. Ayrica iman-amel ilişkisi bağlamında kaleme aldığı "İman" adlı makalesi Kelâm ve Mezhepler Tarihi alanına katkı sağlayabileceği düşüncesiyle sadeleştirilerek değerlendirilmiştir. İman-amel ilişkisi gibi teolojik meseleler, İslâm âleminin değişik dönemlerinde tartışılan kanular arasında yer alır. Bu konu ilk defa Siffin Savaşı'ndan sonra Haricîler'in imanı yeniden tanımlayarak büyük günah işleyenleri tekfir etmesi ile gündeme gelmiştir. Hâricîler imanı tanımlarken ameli imana dâhil etmişler ve küçük dahi olsa günah işleyen kişinin kâfir olacağına hükmetmişlerdi. Sözkonusu mesele Osmanlının son dönemlerinde İslâm uleması tarafindan da tartışılmıştır. Gelenekçi çizgide yer alan ulema imanı ayrı, ameli ayrı olarak değerlendirmiştir. Fakat Tatar ulemasından ve aynı zamanda yenilikçi çizgide bulunan Mûsâ Cârullah, iman-amel ayrımı yapmamıştır. O, Ehl-i Sünnet'in iman-amel ayrımının bazı yanlışlıklarına işaret etmiştir. Bu konu ile ilgili görüşlerini ve gelenekçi çizgide yer alan ulema hakkındaki eleştirilerini ortaya koymuştur.
\end{abstract}

Mûsâ Cârullah, İslâm dünyasının durumu ile itikadî mezhepler arasında çok büyük bağlantıların olduğuna işaret etmiştir. İslâm âleminde yaşanan siyasî olayların ya itikadî mezheplerden kaynaklandığ ya da itikadî mezheplerin siyasî olaylara göre tertip edildiğini belirtmiştir. Özellikle Eş’arîlerin ortaya koyduğu ilkelerin, ahlakın ve siyasetin bozulmasına zemin hazırladığı, Sünnîlik ile Şî̀lik gibi mezhepler arasındaki ihtilafların ise Müslümanlar arasında ayrılıklara ve hatta düşmanlıklara neden olduğu görüşündedir. İslâm âleminde yaşanan siyasî olayların gerçek nedenlerini Müslümanların itikatlarına bağlamıştır. Insanın itikadı; iradesine, ahlakına ve bütün hareketlerine tesiri nedeniyle siyasî olayların gerçek nedenleri itikadî mezheplerde aranması gerektigine dikkat çekmiştir. Mezhepler arasındaki ihtilafi ortadan kaldırmayı, kelâmcıların ortaya koyduğu Ehl-i Sünnet anlayışını, dar çerçevesinden kurtarıp Kur'an ve Sünneti merkeze alan oldukça geniş bir alana taşımaya çalışmıştır. İslâm dünyasının gerilemesinde; mezhep taraftarlarının Kur'an-ı Kerim’i kendi mezheplerinin görüşleri doğrultusunda ele alarak dar bir çerçeveye sokması, ictihat kurumunun işlevselliğini yitirmesi, amelin imana dâhil edilmeyerek ayrı değerlendirilmesi, yanlış tevekkül anlayışı, taklit ile birlikte Müslümanları atâlete sevk eden yanlış "kaza" ve "kader" anlayışı etkili olmuştur. Mûsâ Cârullah, mezheplere eleştirel bir yaklaşım sergilemiş, kendisini herhangi bir mezhep ile sınırlandırmamış ve İslâmı mezheplerden üstün tutmuş, genellikle mezhepler ile ilgili eleştirilerinde ölçülü bir metot kullanmiştır. Hayatı boyunca hiç kimseye kendi görüşlerini benimsetme çabası içinde olmamış ve aklı hapseden mezhep taassubuna şiddetle karşı çıkmıştır.

Anahtar Sözcükler: Kelâm, Mûsâ Cârullah, İman, Amel, Büyük Günah.

\footnotetext{
* Dr. Öğr. Üyesi, Osmaniye Korkut Ata Üniversitesi/İlahiyat Fakültesi/Temel İslam Bilimleri Bölümü/Kelam ve İtikadi İslam Mezhepleri Anabilim Dal1, suleymancam@osmaniye.edu.tr , https://orcid.org/0000-0002-4588$\underline{8491}$
} 


\section{Giriş}

İman, kelâm ilminde üzerinde en çok durulan ve ayrıntılı bir şekilde ele alınan konulardan biridir. Bunun sebebi, imanın dinin merkezinde yer almasıdır. Kelâm ekolleri farklı iman tanımları yapmışlardır. İman; İslâm lügatinde mutlak itâat ve mutlak tasdik manasına gelmektedir. ${ }^{1}$ Ehl-i Sünnet kelâmcılarının çoğunluğu İslâm ile müteradif olarak kullanmıştır. 1stılahta iman; dinî emirleri kalp ile tasdik, dil ile ikrar eklinde tarif edilmiştir. Ehl-i Sünnet kelâmcılarına göre imanın esası kalbin tasdikinden ibarettir. Bazı kelâmcılar ise lügat yönünden İslâm ile iman arasında fark bulunmadığını belirterek, "İman İslâmsız, İslâm ise imansız olamaz." ilkesini benimsemişlerdir. ${ }^{2}$

İslâm âleminin edebî ve siyasî tarihine bakıldığında kelâmî meselelerden olan imanamel ilişkisinin önemli bir yer oluşturduğu görülecektir. Bu konu İslâm siyasî tarihinde ilk defa Hâricîlerin, Sıffın Savaşı'ndan sonra Hakem Olayı sebebiyle günahkâr saydığı tarafları tekfir etmesi ile gündeme gelmiştir. Hâricîler imanı tanımlarken bütün amelleri ona dâhil etmişler ve küçük dahi olsa günah işleyen kişinin kâfir olacağına hükmetmişlerdi. İmanın asıl rüknü ya da rükünleri nelerdir? Amel, imanın aslî bir rüknü müdür? ${ }^{3}$ Amel imandan bir cüz müdür değil midir? Büyük günah işleyen bir kişinin Müslüman sayılıp sayılmayacağ1 gibi meseleler eskiden beri İslâm uleması arasında tartışılagelmiş ve kelâm kitapları arasında yerini almıştır. Ehl-i Sünnet âlimleri imanın kalp ile tasdik dil ile ikrardan ibaret olduğunu kabul etmişlerdir. ${ }^{4}$ İmâm-1 Âzam Ebû Hanîfe (ö. 150/767) ile Ebû Mansûr elMâtürîdî (ö. 333/944) ve onların yolunu takip edenler, iman-amel ayrımına girmeyerek, iman ile amelin ayrı ve amelin imandan bir cüz olmadığını aklî ve naklî delillerle savunmuşlardır. ${ }^{5}$ Fakat onlar ameli; kâmil imanın tamamlayıcısı olarak görmüşlerdir. ${ }^{6}$ Onlara göre büyük günah işleyen fasık bir mü’min olsa da ameli olmadığı için bir fayda görmeyecektir.7

Önceki dönemlerde olduğu gibi son dönemlerde de itikadî meselelerden iman-amel münasebeti İslâm ulemasının gündeminde kalmaya devam etmiştir. Gelenekçi çizgide yer alan ulema, ameli imana dâhil etmeyerek imanı ayrı, ameli ayrı olarak değerlendiren Ehl-i Sünnet’in görüşünü aynen benimseyerek savunmuştur. Ancak Tatar ulemasından Cârullah, iman-amel ayrımına gitmemiştir. O, amelsiz imanın anlamsız olduğunu söyleyerek, Ehl-i Sünnet’in iman-amel ayırımının yanlışlığına işaret etmiştir. Ehl-i Sünnet ulemasının iman ile ameli ayrı ayrı değerlendirmesinden dolayı İslâm dünyasının pek çok zarar gördüğüne işaret ederek gelenekçi çizgide yer alan ulemaya eleştirilerini İslâm Dünyası dergisinde yayımlanan "İman" başlıklı makalesinde dile getirmiştir.

\footnotetext{
${ }^{1}$ Ahmet Hamdi Akseki, İslâm Dîni, (Ankara: 1969), 53.

2 Ömer Kirşehiri, "Hakikat-1 İman ve İslâm”, Cerîde-i Sûfiyye, 1/1, (6 Mart 1325), 1-2.

${ }^{3}$ Bkz: Hasan Fehmi, Risâle-i İman, (Üsküp: Kosova Vilâyet Matbaası, t.y.), 19-28.

4 Mehmed Emin b. Hasan b. Hüseyin el-Ofi, İman Risalesi, (İstanbul: 1317); İbrahim Kaplan, Kelâm III, edt. İsmail Ş1k-Nail Karagöz, (Ankara: Gece Kitaplı̆̆1, 2017), 49-62.

5 Akseki, İslâm Dîni, 58; Ahmet Ak, "Ebü'l-Muîn en-Nesefî̀ye Göre İman-Amel İlişkisi”, Dinî Araştırmalar, 8/24, 2006, 245-252.

6 Rifat, Delâilü'l-İkan fî Beyan-ı Kavâidi't-İmân, (Dersaadet: Mahmut Bey Matbaası, 1316), 115.

7 Naki, H., "İman-İnsan", Medrese İtikadları, 4, (27 May1s 1329), 26.
} 


\section{Mûsâ Cârullah Bigiyef Efendi'nin Hayatı ve Eserleri}

\section{1. Hayat1}

Bir Tatar Türk olan Mûsâ Cârullah'ın yaşadığı yıllar Osmanlı Devleti'nin yıkıldığı ve Anadolu'da Cumhuriyet rejiminin kurulduğu döneme denk gelir. O, Türk tefekkür tarihinin önemli şahsiyetlerinden biri olarak bilinir. 1875 y1lında Rostov-Na-Don şehrinde doğan Cârullah, Kazan Türklerindendir. Babası Molla Cârullah, annesi ise asil bir Türk soyuna mensup olan Şeyh Habîbullah Efendi'nin kızı Fatma Hanım'dır. Cârullah, soyca Nogay Türklerinin Altığul sülâlesine dayanmaktadır. Babas1, o dönemlerde medreselerde eğitim gördükten sonra imamlık yapmış ve ticaretle uğraşmıştır. Cârullah, büyük atalarının adı olan "Bigi" soyadını kullanmıştır. ${ }^{8}$

Babasını küçük yaşta kaybeden Cârullah, annesi Fatma Hanım tarafından okutulup yetiştirildi. İlk, orta ve lise öğrenimini onun yanında tamamladıktan sonar yükseköğrenimini Kazan'da ve Buhara'da çeşitli medreselerde fikıh, felsefe ve matematik gibi dersleri tehsil etti. Kur'an'ı ezberleyerek birçok alanda kendisini yetiştirdi. ${ }^{9}$ Ayrıca Türkçe ve Rusça gibi dilleri özellikle de Arapça ve Farsçayı öğrendi. Buhara'da tahsili sırasında 1slahatçı olarak bilinen İkram Efendi ile Ivaz Efendi'den fikıh ve felsefe, Şerif Efendi'den matematik ve asrtronomi dersleri aldı. Pisagor, Arşimend, Oklid, Eflâtun, Aristo, Descartes, Bacon gibi ilim adamlarını tanıdıktan sonra onların düşüncelerinden etkilendi. Rusça bilmeyen hocalarına destek olmak gayesiyle matematikle ilgili bazı eserleri Rusçadan Türkçeye çevirdi. Buhara'da İslâmî ilimler yanında matematik, astronomi ve felsefe alanlarında da kendisini yetiştiren Cârullah, tahsilini derinleştirmek üzere İstanbul'a geldi. Hocaları ve yakınlarının isteği üzerine yeniden İslâmî ilimler tahsiline yöneldi ve bu amaçla Mısır’a gitti. Ezher Üniversitesi'nde okuduğu yıllarda Muhammed Abduh ile tanışarak onun derslerine katıld1. Hicaz ve Hindistan'a da giden Cârullah, Kur'an ilimleri ve Kur'an tarihi üzerinde araştırmalar yaptı. Buhara, Türkiye, Mısır, Şam, Mekke ve Medine gibi önemli ilim merkezlerinde İslâmî ilimleri tahsil etti. Cârullah, 1904 senesinde Arapça, Farsça ve İslâmî ilimlere vâkıf bir şekilde ülkesine geri döndü. Ancak, gezip gördüğü medreselerde ezber ve taklide dayalı eğitim sistemini görünce hayal kırıklıkları yaşadı. Bu tür eğitim sistemine karşı 1slah ve yenilik fikirlerinden etkilendi. Ona göre Müslümanlar medreselerin 1slahından başlayarak ekonomik, siyasî ve toplumsal gibi önemli meseleleri çözmeleri gerekirdi. ${ }^{10}$ Müslümanların Luther’i olarak bilinen Cârullah 1949 yılında Kahire'de vefat etti. ${ }^{11}$ Ayrıca onun, Abdunnasır Kursavî, Şehabeddin Mercânî, Rıza Fahreddin gibi Rusya

\footnotetext{
8 Ahmet Kanlıdere, Kadimle Cedit Arasında Mûsâ Cârullah: Hayatı-Fikirleri-Eserleri, (İstanbul: Dergâh Yayınları, 2005), 23-24; Osman Keskioğlu, "Mûsâ Cârullah, Hayat1, Görüşleri ve Eserleri", Ankara Üniversitesi İlahiyat Fakültesi Dergisi, 12, (1964), 63; Mustafa Rahmi Balaban, "Mûsâ Cârullah, Hayat1, Felsefesinden Birkaç Çizgi, Eserleri”, İslâm Tetkikleri Enstitüsü Dergisi, 1/1-4, (1954), 173.

${ }^{9}$ Mehmet Görmez, Mûsâ Cârullah Bigiyef, (Ankara: TDV Yayınları, 1994), $20-29$.

10 Ahmet Kanlıdere, "Mûsâ Cârullah", Türkiye Diyanet Vakfi İslâm Ansiklopedisi, (İstanbul: TDV Yayınları, 2006), 31/ 214; Hamdi Mert, "Mûsâ Cârullah Bigiyef-Hayatı, Mücadelesi, Fikirleri-", Bilig: Türk Dünyası Sosyal Bilimler Dergisi, 8, 1999, 126-127.

11 Görmez, Mûsâ Cârullah Bigiyef, 20-29.
} 
Müslümanlarının ceditçilik hareketinin en önde gelen simalarından biri olduğu ifade edilmektedir. ${ }^{12}$

\section{2. Eserleri}

Mûsâ Cârullah, birkaç Arapça eseri dişında genellikle Tatar ve İstanbul Türkçesini kullanmıştır. Yüzden fazla eseri ve birçok makalesi bulunmaktadır. Ahmet Kanlıdere'nin ifadesiyle O'nun eserlerinde genel olarak ele aldığ1 konular şu şekildedir: "Rusya Müslümanlarının siyasî ve ictimaî tarihi, Kur'an araştırmaları, İslâm hukuku ve ilahiyatına dair bazı meseleler, faiz, İslâmî banka, kadın meselesi, medreselerin 1slahı, Türk-Tatar dili ve edebiyatı."13 Yazılan eserlerin sayısı ve içerdiği konular onun çok yönlü bir düşünür olduğunu ortaya koymaktadır. ${ }^{14} \mathrm{Bu}$ eserlerin bir çoğu matbûdur. Ancak başta Kur'an tercümesi olmak üzere diğer yazma eserlerinin günümüze kadar tespit edilemediği belirtilmektedir.15 Eserlerinden en önemlileri şunlar sayılabilir: Büyük Mevzularda Ufak Fikirler16, Edebiyât-ı Arabiye ile Ulûm-ı İslâmiyye; İslâmî İimler Üzerine Eleştiriler ${ }^{17}$, Halk Nazarina bir Niçe Mesele ${ }^{18}$, Hatun ${ }^{19}$, İlâhî Adalet, Rahmet-i İlâhiye Bürhanlarin' ${ }^{20}$ İslâm'in Elifbası ${ }^{21}$, Kavâid-i Fıkhiyye ${ }^{22}$, K. Kerim Âyeti Kerimelerinin Muciz İfadelerine Göre Ye'cûc', el-Lüzûmiyyat ${ }^{24}$, İslâm Şeriatı'nın Esaslari ${ }^{25}$, Tarihü'l-Kur'an ve'l-Mesahif26, Kur'an Tercüme-i Şerife $e^{27}$, Uzun Günlerde Oruç28, Kitâbus-Sünne ${ }^{29}$, Zekât ${ }^{30}$.

12 Rifat Suyargulov, “Mûsâ Cârullah'ın İlahi Rahmetin Genişliği Hakkındaki Düşüncesinin Değerlendirilmesi”, Dinî Araşturmalar, 20/52 (2017), 203.

${ }^{13}$ Kanlıdere, "Mûsâ Cârullah'ın Eserleri Hakkında Bilgiler, Ölümünün 50. Yıldönümünde Mûsâ Cârullah Bigiyef (1875-1949" I. uluslararası Mûsâ Cârullah Bigiyef Sempozyumu, (Ankara: TDV Yayınları, 2002), 224.

14 Raim Gafarov, Mûsâ Cârullah Bigiyef'in Kader Hakkındaki Görüşü, (Bursa: Uludağ Üniversitesi, Sosyal Bilimler Üniversitesi, Yüksek Lisans Tezi 2009), 27.

15 İbrahim Maraş, Türk Dünyasında Dinî Yenileşme (1850-1915),(İstanbul: Ötüken Yayınları, 2002), 88.

16 Musa Bilgiz tarafından sadeleştirilerek yayımlanmıştır. Büyük Mevzularda Ufak Fikirler, haz. Musa Bilgiz, (Ankara: Kitabiyat 2001)

17 Ferhat Koca tarafından sadeleştirilerek yayımlanmıştır. Edebiyât-ı Arabiye ile Ulûm-ı İslâmiyye; İslâmî İlimler Üzerine Eleștiriler, Sad. Ferhat Koca, (Ankara: Ankara Okulu Yayınları 2019)

18 Kubbealtı-Sahaf Yayınevi tarafından 2019 yılında Osmanlıca olarak yeniden basılmış olup tespit edebildiğimiz kadarıyla henüz sadeleştirilmesi yapılmamıștır.

19 Mehmet Görmez tarafından sadeleştirilerek yayımlanmıştır. Hatun, haz. Mehmet Görmez, (Ankara: Kitabiyat 1999)

20 Mûsâ Cârullah'ın Mustafa Sabri ile birlikte hazırladığı bu eser Ömer Hakan Özalp tarafından sadeleştirilerek yayımlanmıştır. İlâhî Adalet, Rahmet-i İlâhiye Bürhanları, sad. Ömer Hakan Özalp, (İstanbul: Pınar Yayınları 1996)

21 Musa Cârullah'ın bu eseri, İbrahim Maraş ve Seyfettin Erşahin tarafından sadeleştirilerek yayımlanmıştır. İslâm'in Elifbası, haz. İbrahim Maraş-Seyfettin Erşahin, (Ankara: Seba Yayınları, 1997)

22 Ferhat Koca, Fatih Karataş ve Ahmet Yasin Küçüktiryaki tarafından derlenerek yayımlanmıştır. Kavâid-i Fikhiyye, (Ankara: Ankara Okulu Yayınlar1 2018)

${ }^{23}$ Nur Ahmed Kurban tarafından sadeleştirilerek yayımlanmıştır. "Kur’ân-1 Kerim Âyetlerinin Mu'ciz İfadelerine Göre Ye'cûc", Sad. Nur Ahmet Kurban, Gümüşhane Üniversitesi İahiyat Fakültesi Dergisi, 2/4, (Temmuz 2013), 250282. Ayrıca yazarın bu eseri Ankara Okulu Yayınların'da 2019 tarihinde bir kitap olarak basılmıştır.

${ }^{24}$ Mehmet Mürşit Tekin tarafından Türkçeye çevrilerek yayımlanmıştır. el-Lüzûmiyyat, çev. Mehmet Mürşit Tekin, (İstanbul: Endülüs Yayınları, 2019)

25 Hatice Kübra Görmez tarafından derlenerek yayımlanmıştır. İslam Şeriatının Esasları, haz. Hatice Kübra Görmez, (Ankara: Kitâbiyât, 2002)

26 Arapça olan bu eser Fethi Ahmet Polat tarafından Türçeye çevrilmiştir. Târihu'l-Kur'ân ve'l-Mesâhif, çev. Fethi Ahmet Polat, Marife: Dini Araştırmalar, 10/1. (Konya, 2010), 177-199.

${ }^{27}$ Kayıp meal olarak bilinen bu eser üzerine Nur Ahmet Kurban tarafından bir değerlendirme yapılmıștır. Bkz. Nur Ahmet Kurban, "Mûsâ Cârullâh'ın (1875-1948) Yaptığı Tatarca Kur'ân Tercümesi Üzerine Bir Değerlendirme", Türkoloji Araştırmaları, 11/17, (2016), 467-489.

28 Yusuf Uralgiray tarafindan sadeleştirilerek yayımlanmıştır. Uzun Günlerde Oruç, sad: Yusuf Uralgiray, (Ankara: Kazan Türkleri Kültür ve Yardımlaşma Derneği Yayınları1975)

29 Mehmet Görmez tarafından tercüme edilerek yayımlanmıştır. Kur'an Sünnet İlişkisine Farklı Bir Yaklaşım Kitâbus-Sünne, trc. Mehmet Görmez, (Ankara: Ankara Okulu Yayınları, 1998) 
$\mathrm{Bu}$ çalışmaların dışında Rusya Müslümanlarının siyasî faaliyetleri, insan hakları, mektep ve medreselerin 1slahı gibi konularda Ülfet ve et-Tilmiz adlı gazeteler yanında elIslah, İ, Vakit, el Asrü'1-cedîd gibi yenilikçi gazete ve Şura ve Minber gibi dergilerde yazıları yayımland1. ${ }^{31}$ Osmanlı matbuatında ise İslâm Dünyası, Türk Yurdu, Selâmet, Şûra, Tearüf-i Müslimin, Strat-ı Müstakim ve Sebilü'r-Reşad gibi dergilerde çeşitli konuları içeren makaleleri yanında Kırım'da Asrî Müslümanlık ve Mısır'da el-Menar ile el-Fetih gibi dergilerde de yazıları bulunmaktadir. ${ }^{32}$

\section{Bazı Teolojik Fikirleri}

Mûsâ Cârullah, Türk İslâm dünyasına kendine özgü fikirleriyle katkı sağlayan önemli bir şahsiyettir. Onun, tefsir, hadis, fikıh ve fikıh usulü, kelâm ve tasavvuf gibi alanlarda ileri sürdügü farklı görüşleri bulunmaktadır. Görüşlerinin sadece Türkistan uleması tarafından değil, İslâm coğrafyasının farklı bölgelerinde de eleştirildiği belirtilmektedir. ${ }^{33}$ Ancak çalışmamızın sınırlılıkları açısından ona yöneltilen eleştirilere yer vermeyeceğiz. Sadece bazı kelâmî görüşlerini ${ }^{34}$ hatırlatmakla yetineceğiz.

\section{1. İman Anlayışı}

Mûsâ Cârullah, imanı; "Kalpte karar kılan bir itikat olması şartıyla, insanın ahlakına, iradesine ve hareketlerine tesir eden hatta ahlakın ve bütün hareketlerin ruhudur" şeklinde tarif eder. İmanı, İslâm dininin en önemli rüknü olarak gören Cârullah, bu bağlamda insanın imanına ufak gözle bakanları eleştirir. İslâm akîdesine desîse yoluyla veya gafletten dolayı bazı zararlı görüşler girdiğini ve bunların zamanla imanın cüzlerinden sayıldığını ifade eder. Mûsâ Cârullah, Buhârî'de geçen "İman, yetmiş küsur şubeye ayrilır..." 35 hadisine istinaden amel, itikad ve ahlakın imanın rükünlerinden olduğuna ancak amelin sınırlı olmadığına dikkat çeker. Ona göre iman; aklın bedenin melekelerini genişleten ameller, devletin ve insanın mutluluğunu sağlayan güzel ahlak ve temiz duygulardan ibarettir. ${ }^{36}$

Mûsâ Cârullah, imanda resmiyetin ve mezhebin olmadığını savunur. Ona göre Kelimei Tevhidi samimi bir şekilde söyleyene Eş’arîlik, Mu’tezile, Şiîlik ve Sünnîlik gibi ihtilaflara itibar etmek kesinlikle haramdır.37 O, imanın sosyal hayata yansıması gerektiği görüşündedir. Ona göre, "İmanda da dinde de hakkaniyetle beraber siyasî ve sosyal faydaların da bulunması gerekir." Cârullah, bazı Ehl-i Sünnet âlimleri tarafından "kalp ile

\footnotetext{
30 Ferhat Koca tarafından sadeleştirilerek yayımlanmıștır. Zekât, sad. Ferhat Koca, (Ankara: Ankara Okulu Yayınları, 2019), Mûsâ Cârullah'in diğer eserleri için bkz: Kanlıdere, "Mûsâ Cârullah", 215-216; Balaban, "Mûsâ Cârullah",177-178; Mert, "Mûsâ Cârullah Bigiyef",135-138.

${ }^{31}$ Görmez, Mûsa Cârullah Bigiyef, 22-29.

32 Mert, "Mûsâ Cârullah Bigiyef", 136-137.

33 Kurban, "Mûsâ Cârullâh'in Yaptığı Tatarca Kur’an Tercümesi Üzerine Bir Değerlendirme”, 469.

${ }^{34}$ Bkz. Akif Savaş, Kelâmın Yenileşme Sürecinde Mûsâ Cârullah Bigiyef, (İzmir: Dokuz Eylül Üniversitesi, Sosyal Bilimler Enstitüsü, Yüksek Lisans Tezi, 2010), 32-74.

35 Buhârî, "İman", 2.

${ }^{36}$ Mûsâ Cârullah, "İman-I", İslâm Dünyası, 1/2, (18 Rebîulâhir, 1329-1331), 21-24.

${ }^{37}$ Mûsâ Cârullah, Halk Nazarina Bir Niçe Mesele, nşr. Muhammed Efendi Maksudof, (Kazan 1912), 60-61.
} 
tasdik ve dil ile ikrar etmek" şeklinde ${ }^{38}$ tanımlanan iman anlayışının, İslâm'ın ifsadına sebep olabileceği kanaatindedir. 39

Mûsâ Cârullah, Ehl-i Sünnet'in itikadî mezheplerin iman-amel ilişkisi hususunda ortaya koydukları görüşlerine eleştiriler yöneltir. İslâm dünyasının ahvalleri ile itikadî mezhepler arasında çok büyük bağlantının olduğunu düşünmektedir. Ona göre İslâm dünyasında yaşanan siyasî olaylar ya itikadî mezheplerden ya da itikadî mezhepler siyasî olaylardan etkilenerek tertip edilmiştir. Özellikle de itikadî mezheplerden Eş’arîlerin ilkeleri, ahlakın ve siyasetin bozulmasına en uygun şekilde konulmuştur. Sünnî ile Şî̂ mezhepler arasındaki ihtilaflar, düşmanlıklar, lanetleşmeler ve ayrışmalar üzerine tesis edilmiştir. ${ }^{40}$ Dolayısıyla O, İslâm âleminde yaşanan siyasî olayların gerçek nedenlerini Müslümanların itikadına bağlamıştır. Ona göre insanın itikadı; iradesine, ahlakına etki eder. İnsanın ortaya koyduğu her bir amel akide veya vicdanına göre şekillenir. Bundan dolayı $\mathrm{O}$, siyasî olayların gerçek nedenlerinin itikadî mezheplerde aranması gerektiği görüşünü savunur. ${ }^{41}$

Mûsâ Cârullah, ameli imandan ayırmanın yanlış olduğu fikrindedir. O, kurtuluş reçetesi olarak görülen imanın kalp ile tasdik dil ile ikrardan ibaret sayılıp da akıl, ilim, güzel ahlak, sâlih amel gibi insanı insan yapan değerlerin her birinin imandan çıkarılmasıyla yapılan yanlışlığa dikkat çeker. İmanı tarif ederken dil ile ikrarı imandan saymayıp ameli imandan sayar. Dolayısıyla O, Ehl-i Sünnet inancında benimsenen dil ile ikrar ve kalp ile tasdikten ibaret olan iman anlayışını eleştirir. Ona göre imanı kalpte gizli tutarak dil ile ikrar kalp ile tasdikten ibaret saymak İslâm dininin bozulmasına en büyük sebeptir. Oysa Müslümanı kurtaracak olan güzel ahlak, hayır ve hasenat gibi faydalı hizmetler ihmal edilmiştir. İmanı sadece itikada ve ikrara hasr etmekle İslâm âleminin siyasetinin bozulmasına kapı aralamıştır. ${ }^{42}$ Dolayısyla Onun iman-amel arasında sıkı bir ilişki kurduğunu söylememiz mümkündür. Ancak onun kurduğu bağ, Mut'ezile, Hâricîler, Rafizîler ve Ehl-i Sünnet’in görüşüne benzememektedir. Bilakis onun görüşü Mut'ezile, Hâricî, Rafizî ve Ehl-i Sünnet’in görüşlerine karş1 eleştirel bir nitelik taşımaktadır. ${ }^{43}$ Çünkü ona göre iman ve amel arasında sıkı bir bağ vardır. O, Mut'ezile, Hâricîler ve Rafizîlerin "amel imanın bir parçasıdır" ilkesinden hareketle amel etmeyenin kâfir veya fâsık olacağı fikrini yanlış bulmaktadır. Aynı şekilde O, Ehl-i Sünnet'in "amel imandan hariçtir, zaiddir" görüşlerinin yanlış olduğunu belirtmektedir. ${ }^{44}$

Ehli-i Sünnet âlimlerinden İmam Şâfiî (ö. 204/820) ve bazı hadisçiler ameli imana dâhil etmişlerdir. ${ }^{45}$ Cârullah'ın, "iman hak itikattan, faydalı amellerden, pak hissiyattan

\footnotetext{
38 Bkz: İmâm-1 Âzam Ebû Hanîfe, Fıkh-ı Ekber Şerhi, haz. İsmail Kaya, (İstanbul: Medve Yayınları, 1984), 50-51; Kırşehiri,"Hakikat-i İman ve İslâm", Cerîde-i Sûfiyye, 1/6-4, (8 Teşrînievvel 1327), 3-4.

39 Mûsâ Cârullah, Halk Nazarina, 59.

40 Mûsâ Cârullah, "İman-II", 40.

41 Mûsâ Cârullah, "İman-II", 39.

42 Mûsâ Cârullah, "İman-II", 40.

43 Abdilaziz Kalberdiev, Mûsâ Cârullah Bigiyef in Kelâmî Görüşleri, (Ankara: Ankara Üniversitesi, Sosyal Bilimler Enstitüsü, Yüksek Lisans Tezi, 2004), 17.

${ }^{44}$ Kalberdiev, Mûsâ Carullah Bigiyef in Kelâmî Görüşleri, 17.

${ }^{45}$ Ebü'l-Yüsr el-Pezdevî, Ehl-i Sünnet Akâidi, trc. Şerafeddin Gölcük, (İstanbul: Kayıhan Yayınları, 2017), 236.
} 
yani şu şeylerin heyet mecmuasından ibarettir" ifadesi onun iman-amel meselesiyle ilgili görüşlerinin İmam Şâfî̀ ve bazı ehl-i hadîs gibi sünnî âlimlerin görüşleriyle paralellik arz etmektedir. Ayrıca Onun, Kelime-i Tevhit getiren kimsenin günah işlese dahi dinden çıkmayacağ1 görüşü46 Ahmed b. Hanbel'in (ö. 241/855) düğüncesine yakın olduğunu göstermektedir.

\section{2. Mezhep Anlayış1}

Mezheplere eleştirel bir yaklaşım sergileyen Cârullah siyasî, itikâdî ve amelî-fikhî mezheplerin ileri sürdüğü batıl görüşlerin toplanıp bir araya getirilmesiyle hacimli bir kitabın meydana geleceğini şu ifadeler ile dile getirir. "İslâm mezhepleri, fikıh kitaplarında, kelâm kitaplarında batıl görüşler, fasit kıyaslar o kadar çoktur ki o görüşler seçilerek toplansa hiç kuşkusuz gâyet büyük bir kitap meydana gelir." ${ }^{47}$ Kendisini herhangi bir mezhep ile sınırlandırmayan ve İslâmı mezheplerden üstün tutan Cârullah'ın, genellikle mezhepler ile ilgili eleştirilerinde ölçülü bir metot kullandığı görülmektedir.

Şu ifadeler onun mezhep taassubuna karşı olduğunu açık bir şekilde göstermektedir: "Gerçekten ümmete ömrü boyunca belli bir mezhebi benimsetmek bir kişinin görüşünde hata sadır olan bir kavli, İslâm ümmetinin hayatına ittihaz etmek, bir adamın re'yine taassub edip aklı da, şer'̂̀ nasları da heder itibar etmek, son asırlarda ortaya çıkan kötü bir bid'at ve büyük bir bela dır ki, Allah'nn kitabını, Peygamber'in sünnetini kalbimizden de, elimizden de tamamen gasbettiler." 48 Ayrıca onun, "F1kıh ve kelâm mezheplerinde ihtilafın zararı yoktur, zarar muhalif mezheplere düşmanlıktadır"49 gibi ifadeleri bu konuda geniş bir düşünceye sahip olduğunu ortaya koymaktadır.

Kısaca belirtmek gerekirse Cârullah'ın, "fikıh mezheplerini de, fikir mezheplerini de birleştirmek lazım değil” 50 şeklindeki yaklaşımından hareketle mezheplere karşı olmadığını aksine mezhep taassubuna karşı olduğunu aşağıdaki ifadelerinden de anlamak mümkündür: "Kelime-i tevhid gibi hatt-1 müstakim imtidadiyla İslâmiyet gibi nihâyeti olmayan bir sath-1 müsteva, Seyyidu'l Vücud Hazretlerinin hendese-i ilahiyesi ile resm k1lınmış ise; öyle büyük bir dairede Hanefîleri de, Şafî̀leri de, Malikî ve Hanbelîleri de, Sünnîleri de, Şiîleri de, Zeydîleri de, Caferîleri de elbette ihatasına alabilir."51

Mezhepler üstü52 bir tavir sergileyen Cârullah, âyet ve hadislerin kasdettiği manalardan uzaklaşıldıkça Müslümanların itikatlarındaki saflı̆̆n da aynı şekilde bozulduğu görüşündedir. Dolayısıyla $\mathrm{O}$, dinin aslına dönebilmek için Kur’ân'ı ve Hz. Peygamber'in uygulamalarını en iyi bilen Selef'in metodunu örnek alınması gerektiğine

\footnotetext{
46 Mûsâ Cârullah, Halk Nazarina, 52.

47 Mûsâ Cârullah, el-Lüzûmiyât Tercümesi, Kazan 1907, 192.

48 Mûsâ Cârullah, Halk Nazarina, 60.

49 Mûsâ Cârullah, Büyük Mevzularda Ufak Fikirler, Petersburg 1914, 15.

50 Mûsâ Cârullah, Büyük Mevzularda, 15.

51 Mûsâ Cârullah, Büyük Mevzularda, 15.

52 Mûsâ Cârullah, Halk Nazarina, 39.
} 
inanmaktadır. ${ }^{53}$ Kur'an ve Sünnetle amel eden herkesi ve her mezhebi Ehl-i Sünnet dairesi içinde değerlendirmektedir.

Cârullah'a göre, mezhep taraftarlarının Kur'an'ı kendi mezheplerinin görüşleri doğrultusunda ele alarak dar bir çerçeveye sokması, ictihat kurumunun işlevselliğini yitirmesi ve taklitçiliğin önünün açılması ile İslâm dünyası gerilemiştir. Bunda da İslâm fukahasının önemli rolü bulunmaktadır. ${ }^{54}$ Mezhepler arasındaki ihtilafı ortadan kaldırmayı, kelâmcıların ortaya koyduğu Ehl-i Sünnet anlayışını, dar çerçevesinden kurtarıp Kur'an ve Sünneti merkeze alan oldukça geniş bir alana taşımaya çalışmıştır.

Mûsâ Cârullah, farklı mezheplerin ortaya çıkışını İslâm dininin akla büyük önem vermesine bağlar. Ancak sonraki âlimlerin tutumu yüzünden bu fikrî özgürlüğün yok olduğunu belirterek mezhep taassubuna tepki gösterir. Ona göre kelâm ilmi Müslümanların zihinlerini gereksiz tartışmalarla meşgul etmiş, İslâm'ın saf olan akîdesini karmaşık hale getirmiştir. Dolayısıyla Cârullah, Kur'ân-1 Kerîm'i ve Hz. Peygamber’in uygulamalarını en iyi bilen Selef'in yolunun örnek alınması gerektiğine inanmaktadır. ${ }^{55}$

\section{3. Kaza ve Kader Anlayışı}

Kelâm ilminin ve itikadî mezheplerin teşekkülünde önemli bir yere haiz olan kaza ve kader inancı, İslâm'ın ilk dönmelerinde tartışılan konular arasında yer almaktadır. Bu konudaki tartışmalar tarihin her döneminde gündeme gelmiştir. Herkes tarafından üzerinde fikir yürütülen hassas bir konu olan kaza ve kader, yanlış yorumlanan dinî inançların başında gelmektedir.56 Öncelikle şunu belirtmemiz gerekir ki Cârullah, kaza ve kader konusunda kesin ve açık deliller bulunmadığından asırlarca tartışılan bu konunun itikadî meseleler içine sokulmasını doğru bulmamaktadır. 57

Mûsâ Cârullah, İslâm dünyasının gerilemesinde yanlış "kaza" ve "kader" anlayışının etkili olduğu görüşündedir. $O$, Müslümanların miskinleşmesine, fakirleşmesine ve köleleşmesine neden olan yanlış kader anlayışı hususunda şu ifadeleri kullanmıştır: "İmanda ehemmiyeti yok olan kaza ve kaderi, imanın en büyük rükünlerinden hesap ettikten sonra kaza ve kaderi son derece yanlış tefsirlerle İslâm ehlinin gönüllerini emelden, ellerini amelden ve ayaklarını hareketten engellediler. İftira ve şaşırtma yoluyla kendi çıkarlarını düşünerek ve "Allah'in hükümlerine razı olmak" ifadesini ileri sürerek bu yönü istismar ettiler. Süslü ifadelerle bunu tezyin kılıp imanın rüknü sıfatılla gösterdiler."58

O, insanın başına gelen musibetleri kadere bağlamamıştır. "Sultan Aziz’in Kusurları ne idi?” başlıklı bir yazısında Müslümanların başına ne geldiyse kendi yüzlerinden olduğunu şu sözleriyle ifade etmektedir: "Düşmanın büyük kuvveti, büyük mahareti değil, bütün

\footnotetext{
53 Kanlıdere, "Mûsâ Cârullah", 215.

54 Mûsâ Cârullah, Uzun Günlerde Oruç, sad. Yusuf Uralgiray, Ankara 1975, 49.

55 Kanlıdere, "Mûsâ Cârullah", 215.

56 Süleyman Çam, Osmanlı'dan Cumhuriyet'e Geçiş Sürecinde Mezhep Tartışmaları, (Adana: Çukurova Üniversitesi, Sosyal Bilimler Enstitüsü, Doktora Tezi, 2019), 308.

57 Maraş, Türk Dünyasinda Dinî Yenileşme, 127.

58 Mûsâ Cârullah, Uzun Günlerde Oruç, 230.
} 
ahvalin as1 sebebi bizim büyük gafletimizdir."59 O, kaderi; insanı yaprak gibi ağaçtan koparıp istediği yöne sürükleyen rüzgar olarak görmemekte, bilakis insanın seçme kabiliyeti ve fiillerinde özgür olduğunu inanmaktadır. Her şeyin insanın dünyaya gelmeden önce kaderle belirlenip, insanın sadece bir kukla olduğu tezini savunan Cebrî anlayışa karşı çıkmaktadır. Ona göre insan doğruyu, yanlışı seçebilecek ve kendi kaderini kendi belirleyebilecek güçtedir. ${ }^{60}$

\section{3. İslâm Dünyası Dergisi ve İman Adlı Makalesi}

\section{1. İslâm Dünyası Dergisi}

İslâm Dünyası dergisi, Osmanlı Devletinin zor günler geçirdiği bir dönemde Tatar Müslümanlarından Abdürreşid İbrahim tarafından 1913-1914 yılları arasında iki haftada bir çıkartılan İslâmcı dergilerden biridir. Dergi; İslâm dini adına dinle alakası olmayan birçok kişinin yayımladığı dergilerde insanların yalan yanlış bilgilendirilmesine tepki göstermeyi, başta Osmanlı olmak üzere İslâm dünyasının sorunlarını ele alarak bütün Müslümanları içinde bulunduğu ataletten, miskinlikten, tembellikten, uyuşukluktan uyandırmayı ve İttihâd-1 İslâm vurgusunu ön plana çıkarmayı amaçlamıştır. ${ }^{61}$ Dergi, Osmanlıyı merkeze alarak bütün dünya Müslümanların durumu hakkında bilgi vermektedir. Dergide İslâm'ın birleştirici gücü ve Müslümanların akıllarını kullanmasıyla dünya Müslümanlarının batı karşısındaki ezilmişliğinin bir an evvel sonlandırılmasının mümkün olabileceği yönünde Osmanlı Müslümanlarını harekete geçirecek yazılar bulunmaktadir.

Dergide daha çok Tatar-Cedit hareketi içersinde yer alan yazarlar bulunmaktadır. Derginin baş yazarı ve kurucusu Abdürreşid İbrahim'dir. Bunlarla birlikte Mûsâ Carullah Bigiyef, Abdülvahhab, Hadimüddin, Kerîmzâde İsmail Hakkı, Samizâde Süreyya, Ebu'l Kemal, Hoca Mahmud Behbudi, Mehmed Gryaseddin, Şeyh İsmail Safâihi ve Abbas Hilmi derginin önde gelen yazarları arasında yer almaktadır. Dergi 27 sayı yayınlandıktan sonra yine İslâmcı çizgide yer alan İslâm Mecmuası'nın yayın hayatına başlamasıyla 16 Nisan 1914 'te yayın hayatına son vermiştir. ${ }^{62}$

\section{2. İman Adlı Makalesi}

Mûsâ Cârullah, Osmanlı Devletinin yaşadığı buhranın ancak İslâm akîdesinde önemli bir yeri olan iman sayesinde düzelebileceği düşüncesiyle "İman" adlı makaleler yazmıştır. Söz konusu makaleler, "Halk Nazarına Bir Niçe Mesele" adlı eserinden alınarak İslâm Dünyası dergisinde Osmanlıca olarak neşredilmiştir. Onun "İman-I" adlı makalesi 14 Mart 1913’te derginin ikinci sayısında, “İman-II” isimli makalesi 28 Mart 1913’te üçüncü sayısında, “İman-III” başliklı makalesi ise 11 Nisan 1913’te dördüncü sayısında

\footnotetext{
59 Mûsâ Cârullah, Tarihin Unutulmuş Sahifeleri, (Berlin: 1933), 7.

60 Gafarov, Mûsâ Cârullah Bigiyef'in Kader Hakkındaki Görüşü, 45-46.

61 Abdürreşid İbrahim, "Ac1 Hakikatler İtiraf Olunmadikça Islah Mümkün Olamaz", İslâm Dünyası, 6 Rebiülahir 1329-1331 (2 Mart 1913), 1-3; Ayrica bkz. Abdülvahhab, "Ak1l", İslâm Dünyast, 2, (14 Mart 1913), $19-21$.

62 Nadir Özbek, “Abdürreşid İbrahim İslâmc1 Bir Eylem Adamı”, Toplumsal Tarih, 4/19, $1995,8$.
} 
neşredilmiştir. Makalenin orijinal metnini derginin belirtilen tarih ve sayılarında görmemiz mümkündür. ${ }^{63}$ Orjinali Osmanlıca olan bu makale Kelâm ilmi açısından faydalı olabileceği düşüncesiyle sadeleştirilmeye çalışılmıştır.

\section{2. 1. İman-I ${ }^{64}$}

"İslâm dünyasının edebî ve siyasî tarihinde iman meselelerinin büyük önemi vardır. İman, kalbin tasdiki ile gerçekleşen bir itikat olması yönüyle, insanın ahlakını, iradesini ve davranışlarını etkiler. Ahlakın ve bütün hareketlerin ruhudur. Dolayısıyla, doğru inançlardan, temiz duygulardan ibaret olan iman, İslâm dininin en mukaddes rükünlerinden sayılıp dünya ve ahirette kurtuluş sebebi olmuştur.

Bunun için, insanın imanına küçümseyerek bakan mezheplere rahat bir şekilde karşı çıtım. İslâm dinine göre en kutsal sayılan İslâm akîdesine, hile yoluyla batıl inanışlar veya yanlışlıkla kabul edilen bazı yanlış görüşler girmiştir. Ancak bu yanlışları temizlemek çok zor bir şeydir. Çünkü İslâm dinine girmiş olan yanlış inanışlar zamanla imanın bölümleri gibi görülmektedir. Buna engel olmak gerçekten de çok zor ve meşakkatli bir iştir. Maksadın anlaşılması yönüyle şüpheye düşenler, sarf edilen sözleri anlamsız gibi görenler vardır. Dolayısıyla buna her insan cesaret edemez. Fakat ben susmayacağım. Dünya ve ahirette kurtuluş sebebi olacak olan iman, bozguncuların en ileri gelenlerine bile alet edilmissken duyarsız kalmak büyük günahtır.

$\infty$

İmana, imanın rükünlerine, felsefesine, insanın bütün düşüncelerine faydalı olması yönüyle önem veririm. Bir eğitimde hakkaniyet ve menfaat bulunursa o eğitim elbette kabul görür. Faydasız olduğu bilinen veya zararı belli olan bir eğitim bana göre her durumda makbul değildir. İmanın da, dinin de hakikatle birlikte siyasetten arınmış bir şekilde topluma faydalı olması gerekir. Tecrübeye, akla ve menfeate aykırı olan şeylerin hiçbiri ne dindir ne de imandir.

$\mathrm{Bu}$ nedenle bana göre iman; doğru inanç, sâlih amel ve temiz duyguların toplamından ibarettir. Doğru bir inancın önemi de sadece amelde ortaya çıkan eseriyle belli olur. İnanç, insanın ahlakına, amellerine tesir ederse zarardan uzaklaştırıp insanı faydalı şeyler yapmaya yönlendirirse işte o zaman böyle bir itikat geçerli olur. İnsanın amelinde ortaya çıkmayan inancın hiçbir hükmü yoktur.

Peygamber Efendimiz: “İman yetmiş küsür özelliktir. En yükseği, 'Allah’tan başka ilâh yoktur' demek; en aşağısı ise, insane zarar veren şeyleri yoldan kaldırmaktır. Hayâ da imanın bir bölümüdür."65 buyurmuştur.

\footnotetext{
63 Mûsâ Cârullah, "İman-I", İslâm Dünyası, 1/2, (18 Rebîulâhir, 1329-1331), 21-24; Mûsâ Cârullah, "İman-II", İslâm Dünyası, 1/3, (3 Cemâziyelevvel, 1329-1331), 38-42; Mûsâ Cârullah, "İman-III", İslâm Dünyası, 1/4, (17 Cemâziyelevvel, 1329-1331), 52-54.

${ }^{64}$ Mûsâ Cârullah, "İman-I", İslâm Dünyası,1/2, (18 Rebîulâhir 1329-1331), 21-24.

${ }^{65}$ Buhârî, "İman", 3
} 
Şu kapsamlı ve gâyet açık olan hadis ve mana itibariyle buna eşdeğer hadisler bütün imamlara göre hadis kitaplarında rivâyet edilmiştir. Bu hadislerin açık beyanlarına göre; amel, itikat ve ahlak imanın rükünleridir. O halde imanın rükünleri sınırlı değildir. Rükünlerden en büyüğü ve en efdali Allah'in varlığına ve birliğine iman etmektir. En küçüğü ise eziyet veren şeyleri yoldan kaldırmaktır. İmanın rükünlerinin en aşağısında "eziyet veren şeyleri yoldan kaldırmak" gibi toplumun bir menfaatı olursa diğer rükünlerde de toplumun menfaatı olması elbette mümkündür. Kötü işleri yapmaktan utanmak manasına gelen haya; -hadisin açıklamasına göre- imanın büyük şubesidir.

İmanın en büyüğü; Allah'ın varlığına ve birliğine imandır. Allah'ın varlığı ve birliği kesin bir hakikattır. İnsanların her birine en sade yolla bildirilen şey, doğuştan gelen bir hakikattır. Böyle bir imanın, bireysel ve toplumsal menfaatı oldukça büyüktür. İnsanın kendisine, kendinden yakın her özelliğine kefil olan Allah'ın varlığına iman; yalnızlık ve korku zamanlarında insan için en büyük arkadaş, zor durumlarda ise en büyük belirleyicidir.

İnsanın mutluluğu için gerekli olan kalbin huzuru, iman sayesinde sağlanır. Toplumsal hayatın düzgün yaşanması ancak iman ile mümkündür. Allah'ın varlığına ve birliğine imanın toplumsal ve bireysel faydaları, kalemle yazılamayacak ve dil ile tarif edilemeyecek kadar çoktur. İman ile gönül huzurlu, toplumsal hayat mutlu olur.

Sayısız faydalarına istinaden iman, İslâm akidesinin temelini oluşturmuştur. Hadislerin beyanına göre imanın rükünleri farklıdır. Rükünlerin farklı olması nedeniyle mü'minlerin imandaki dereceleri de farklıdır. Allah'ın birliğine imandan sonra, rükünlerin en önemlileri namaz, oruç, zekat ve hacctır. Bunlardan sonra da yapılan diğer iyilikler gelmektedir.

Din ve insaniyet vazifeleri olan rükünleri tam olarak yerine getiren kimse mükemmel bir mü'mindir. Diğer insanlar hayır ve hasenatları nispetinde derece derece mü'min olurlar. Çünkü, iman şu'belerinin rükünleri farklı ve dereceli olduktan sonra mü'minlerin imandaki derecelerinin de farklı olmaması mümkün değildir.

Hadislerin ve Kur'an'ın bildirdiğine göre imanın dereceleri olan hayır, hasenât ve sâlih amelin sadece ahiretle ilgili işlerine mahsus değildir. Belki az çok faydası olan amellerin tamamı imanın şu'besindendir. Aklın, bedenin, bilgi ve maharetlerini genişleten ameller, devlet ve millet yararlarını hakkıyla yerine getiren hizmetler, kendi derecelerine göre hepsi imanın şu’besini oluşturmaktadır. İnsanın ve bütün insanlığın mutluluğuna sebep olabilecek olan iman; doğru inançlardan, hayır ve hasenattan, güzel ahlaktan ve temiz duygulardan ibarettir. Âyetler ve hadisler bu hakikatleri gâyet açık bir şekilde beyan etmiştir.

Bütün mü'minleri kendi gölgesi altına toplayan sancak olması ve mü'minleri kardeş kılan bir şiâr olması sıfatıyla iman; "Lâ ilâhe İllallah Muhammedün Resulullah" kelime-i tevhidi içten ve dil ile söylemekten ibarettir. Bir insan bu sancağın gölgesi altına gelirse bu 
kelime-i tevhidi kendi dili ile söylerse bütün İslâm aleminin kıblesine ihlasla yönelirse o insan, İslâm ümmetinin bir mensubu olmuş sayılır. Kelime-i tevhidle iman gerçekleşir. Müslüman olduğunu gösteren bir alamettir. İslâm dinine göre kapsayıcı olması yönüyle de kutsal bir değerdir. Böyle imanı olan bir insan, hiç amel etmemiş olsa da İslâma olan saygısından dolayı İslâm dairesinden çıkmış sayılmaz, tahkîr ve tekfir edilmez, din ve insanlık haklarından mahrum kalmaz."66

\section{2. 2. İman-II ${ }^{67}$}

İslâm dininin en genel ve en büyük şiârı olan kelime-i tevhid ile gerçekleşen iman, "Mü'minler ancak kardeştirler" (Hucurât, 49/10) âyetin hükmüyle mü’minler arasında manevî bir yakınlık oluşturur. İman yönüyle kardeşlik, genel istek ve arzularda, güzel diyaloglarda, birlik ve beraberlik göstermek düşüncesiyle İslâm siyaseti esasına konulmuştur. İman kardeşliği; "Peygamber mü'minler için kendilerinden daha önceliklidir. Onun eşleri de onların anneleridir" (Ahzâb, 33/6) âyetin hükmüyle kan kardeşliğinden itibar olarak daha üstün sayıldı. Ezvâc-1 Mutahhara, mü'minlerin anneleri, Peygamber ise mü'minlere kendilerinden yakın babaları olursa, iman kardeşliği, hukuk yönüyle kan kardeşliğinden elbette üstün olur.

Bütün İslâm alemi için şu iki âyette belirtilmiş İslâm siyasetini açıklamaktan tamamen acizim. Fakat şu iki âyetin ifadeleri gâyet açıktır ve manaları gâyet geniştir. Kendi başlarına müstakil, biri diğerine her yönüyle birlikte olan Müslüman, kelime-i tevhidle kan kardeş gibi kardeş olursa bütün İslâm dünyası-babaları peygamber olan-büyük aileyi oluşturursa o aile bireylerinin hukuk karşılığı kan kardeşlerin hukuklarından hem fazla hem de kuvvetli olursa Kur'an'in hükümleri o büyük ailede en adil bir şekilde uygulanırsa bundan daha güzel siyaset aramaya gerek kalmaz.

İslâm tarihinde böyle bir siyasetin hükmünün neden uygulanmadığ1 bilinmez. Peygamber zamanında ittihadı sağlayan İslâm toplumu, geçmiş asırda fitnelerin çıkmasıyla parçalandı ve bundan sonra İslâm alemi birlik yüzü görmedi. Hilâfet kavgaları, zalimlerin istek ve arzuları ön plana çıkarılarak dini hükümler terkedildi. İslâm devletleri ise sadece Moğol ve İspanya istilaları ile şiddetli savaşlar karşısında müdafaa amacıyla ancak bir araya gelirlerdi.

Müslüman devletlerin tarihlerine bakan birinin şaşırmaması imkansız gibidir. Çünkü ilk dönemlerde mezhepler arasındaki ihtilaflar gâyet yüzeysel iken daha sonra Müslümanlar birçok tefrikaya düşerek birbirlerine düşman oldular. Diğer taraftan Hiristiyan mezhepler arasında çok büyük ihtilaflar yaşanmasına rağmen birlik ve beraberlik göstermişlerdir. Hıristiyan alemi, şiddetli savaşlar yaşandığında bir araya gelirken, birbirlerine en yakın olan Müslümanlar birliktelik gösteremediler. Güçlü orduları yenen Selahaddini Eyyubi'nin bile o dönemlerde Müslümanları birleştirmeye gücü yetmedi. İslam dünyasına saldırıldığında

\footnotetext{
66 Mûsâ Cârullah, "İman-I", 21-24.

67 Mûsâ Cârullah, "İman-II”, İslâm Dünyası, 1/3, (3 Cemâziyelevvel, 1329-1331), 38-42.
} 
dönemin zahidleri ve velileri tekkelere kapandılar. Haramların yaygınlaştığı farzların terkedildiği bir zamanda dönemin velileri nafile namaz kılmakla meşgul oldular.

Hindistan, Türkistan, İran, Türkiye, Afrika kitalarında ve Volga boylarında bulunan küçüklü büyüklü İslâm devletlerinin durumları bundan daha iyi değildi. Birbirleriyle yaptıkları savaşlar, bozgunculuktan başka bir şey değildi. O dönemde Endülüslerin işledikleri vahşetlere İslâm devletleri tepki göstermezlerdi. Endülüste sadece dininden dolay1 işkence gören ve öldürülen sayısız Müslümanların feryatları duymamazlıktan gelindi. Türkiye devleti o miskinlerin birkaç defa istedikleri yardımları reddetti. Ticarî ve siyasî anlaşmalar gereği Osmanlı Devletine sığınan birtakım Hindistan liderleri yardım talebinde bulunup iltica ederler ancak derhal bu talepleri geri çevrilirdi. Volga boylarında bir Tatar İslâm Devleti kurulunca Ruslar hemen saldırırlardı. Kerim Han yalnız kendi imkanlarıyla o İslâm devletine yardım ederdi. Osmanlı Devleti'nden yardım istediklerinde ise yeniden bir Moğol devleti kurulur korkusuyla Osmanlı hanedanı şiddetle karşı çıkardı. Kanuni Sultan Süleyman, yeniden bir Moğol devleti kurmak arzusunda olan hanedan yakınlarına bu firsatı vermezdi.

İslâm devletlerinin tarihlerine bakıldığında buna benzer olaylar az değildir. Hilâfetin ilk dönemlerinde ayrılıklar ortaya çıkmış ancak daha sonra her geçen gün devam etmiştir. Din kardeşliği İslâm'a göre kan kardeşliği gibi olmasına rağmen İslâm devletleri birbirlerine karşı aşırı düşmanlık göstermişlerdir. Dolayısıyla da birlik ve beraberlikleri enaz olan millet İslâm toplumu olmuştur.

İslâm devletlerinin siyasî durumları ise şöyleydi: Batılı siyasetçiler devletlerine ve vatanlarına bağl1lıkla iftihar ederlerken milletlerinin yararına, izzetlerine ait hizmetlerde son derece gayret ederken, Müslüman devletlerin siyasetçileri hiyanet meydanlarında müsabaka eder gibi hareket ederlerdi. Siyaset dairesinde yapılan hiyanet sınırları aşmıştı. Ancak arada bir güvenilir bir devlet adamı çıkarsa etrafındakilerin etkisinde kalarak o da hyanet yollarına başvururdu. Medenî bir toplum sayılmak için doğruluk, dürüstlük ve temizlik gibi meziyetler gerekirken İslam dünyasında bu üstün meziyetlerin aksine bir yöneliş söz konusuydu.

İslâm dünyasındaki siyasî olayların gerçek sebeplerini belirlemek zordur. Fakat insan akîdesinin, iradesine, ahlakına ve bütün hareketlerine tesir etmesi kaçınılmazdır. İnsanın her bir hareketi, her bir ameli akidesine ve vicdanına göre olur. Buna göre siyasî olayların, edebî durumların gerçek sebeplerini itikadî mezheplerde aramak mümkündür. İslâm aleminin durumuyla itikadî mezhepler arasında gâyet büyük bir ilişki vardır. Bu ilişkiye göre ya siyasî ve edebî durumlar itikadî mezheplere göre veya itikadî mezhepler siyasî olayların durumuna göre tertib edilmiştir. Sanki itikadî mezheplerin özellikle de Eş'arîler’in öğretileri ahlakı bozmaya ve siyaset bozguncularına (müfsidelerine) en uygun şekillerde konulmuştur. Şîa ve Sünnîler arasında zuhur eden ihtilaflar, düşmanlık ve birbirlerini lanetleme gibi ayrılıkların temelini oluşturmuştur. 
İmanı, dil ile ikrar kalp ile tasdik şeklinde tarif etmek resmî sözlerden ibaret kılındı. Akıl, ilim, güzel ahlak, hayırlar ve hasenatlar gibi insanın insaniyetine şart olan ilkelerin her biri kurtuluş reçetesi olan imandan ayrı tutuldu. Yalnız Allah'a malum olan kalp ile tasdik, iman olarak görüldükten sonra, genellikle ayıpların ve günahların perdesi, hal ve hatırın ortaya çıkması için itikadın bizzat kendisi de feda edildi. Sonuç olarak sadece kalpler ve kuru kuruya isimler zahir durumdan bedel kılınıp İslâm, korku ve kuru laftan ibaret bir din sayıld1.

İsmi mü'min olan bir insan ömrü boyunca sarhoşluk veren şeylere dalsa, fuhşiyatın her türlüsünü yapsa, fakirlerin ve yetimlerin mallarını yese, binlerce masumlara zulmetse, kötülüklerin sebebi olsa diliyle şu şeylere helal demedikçe, yalnız isim yönüyle mü'min olur. Kalp ile yapılan gizli tasdikin hatırı için Müslüman olmuş olur. Bazan tövbe istiğfar yoluyla birtakım sözleri de söylerse "lâ kebîraten meal istiğfâr" kaidesine göre o insan hayırlı bir sifatla vasiflandirılır.

İmanı sadece kalp ile tasdik, dil ile ikrardan ibaret saymak İslâm'ın bozulmasına en büyük sebep olmuştur. Çünkü güzel ahlakı, güzel işleri, hayırları ve güzellikleri, çok önemli olan faydalı hizmetleri ihmal edilip, içten gizlice kalp ile tasdik ve dil ile ikrarla yetinme yolları açıldı. İnsanın kurtuluşuna sebep olan iman, sadece kalp ile tasdik ve dil ile ikrardan ibaret olursa, öyle bir iman, insanın kibirlenmesine en büyük etken olur. İnsanın gözünde hayırların ve iyiliklerin önemi kalmaz, şerlerin, fesadın ve hıyanetin cazibesi artar.

İslâm dünyasında siyasetin bozulması da imanı yalnız kalp ile tasdik, dil ile ikrarla sınırlandırma sebebiyle oldu. Sadece kalp ile gizli tasdikten, dil ile ikrardan ibaret sayılmış iman; milletin ve devletin genel işlerinde esas alınıp, zalimlerin ve hainlerin bütün zulümlerine, bütün hyyanetlerine en uygun kalplere empoze edildi. Bir hakim kuru laf sayesinde mü'min olup milletin menfaatleri uğruna birşeyler yapmazsa, zalimlerin, hainlerin en büyüklerini irtikâb edip de imanına hiçbir suretle zarar gelmezse, fakihlerin fetvaları, hileleri sayesinde zulümlerini adalet, fısklarını diyanet gibi gösterebiliyor ise köyleri ve şehirleri harap ettikten sonra, dervişlere dört beş dirhem dağıtmak büyük merhametten sayılırsa, bu memleketi zorla soyup, türbeler ve mescitler yapmak büyük hayırdan sayılırsa, Haccac gibi yüzbinden fazla masumu katletmekAllah'ın haremine ihanet ederek Ka'be'yi yıkmak, veya Yezid gibi Ravza-i Saadeti Harem-i Nübüvveti en kötüşekillerde tahkir edip beyt-i nübüvveti en kötü surette tahrif etmek, işlenen cinâyetler de imanın sağlığına zarar vermez ise, o kadar sağlam iman, bütün fesadın en büyük vesilesi, en sağlam aleti olur. Zalimlerin bütün kötülükleri, hainlerin bütün rezaletleri ve hiyanetleri öyle iman sayesiyle gizlenmişse öyle iman Müslümanların İslâm devletlerinin helakine en güçlü etken olur.

İman meselelerinde kelâm mezheplerine şaşırırım. Dil ile ikrar, kalp ile tasdik edilmiş imanın, tercümesi ve delili olabilirse, insanın ameli, iyilikleri ve kötülükleri daha kuvvetli daha fazla geçerli delil olmaz mi? Dünyevî hükümlerde dil ile ikrar esas kabul edilirse, güzel amel daha güzel esas olmaz mı? İnsan ameline göre mü'min sayılsaydı, dil ile ikrarından 
daha ziyade itimada layık olmazmıdı? "Amel imanın dışındadır, artar" gibi en kaba tabir yerine "Ameller imanın delilidir." Denseydi âyetlerin ve hadislerin ibarelerine, delillerine daha çok uygun, Müslümanların lehine daha çok yararlı olurdu.

Peygamberimizden imanla ilgili şu hadisler rivâyet edilmiştir: 1) "İman yetmiş küsür şubedir, hayada imandan bir şubedir."68 2) "İmanın temeli sabır ve müsamahadır."69 3) "İman, günâh işlemekten kaçınmadır."70 4) "İman ve amel iki kardeş, bir boynuzda iki eş (gibi) dir. Allah, onlardan birini, diğeri olmadan kabul etmez."71 5) "Müslüman, elinden vedilinden Müslümanların selamette olduğu kimsedir."72 6) "Îmânın en üstün mertebesi, nerede olursan ol, Allâh'in seninle beraber olduğunu bilmendir."73 7) "Nefsim elinde olan Allah'a yemin ederim ki sizden biriniz, kendisi için arzu edip istediği şeyi, din kardeşi için de arzu edip istemedikçe, gerçek anlamda iman etmiş olmaz."74 8) "İslâm; sabır, hakikat, cihat ve adalet olmak üzere dört şey üzere bina edildi. Sabır kendi arasında şevk, şefkat, züht ve terakkub olarak dört kısma ayrılır. Kim cennete girmek istiyorsa şehevî şeyleri terketmelidir. Kim de cehennemden korkuyorsa kendini haramlardan korumalıdır. Kim zâhit olarak yaşarsa zorluklar ona kolaylaştırılacaktır. Kim ölümü düşünüyorsa hayır yapmada acele etsin. Hakikât; basîret, hikmet, ibret ve sünnete uymak şeklinde dört şubedir. Basîret sahibi bir kimse hikmetli konuşur. Kim de hikmet sahibi olursa ibret almasını bilir. İbret almasını bilen kimse ise sünnete tabi olur. Cihat; iyiliği emretmek, kötülükten alıkoymak, her yerde ve durumda doğru söylemek ve fâsıklardan nefret etmek şekliyle dört şubeden oluşur. Müslüman birisine yardım etmek iyiliği emretmek demektir. Müslüman bir kimseyi kötülükten alıkoymayanın burnu sürtülsün. Her yerde ve durumda doğru söyleyen kimse ise dinini korumuş ve tamamlamış olur. Fâsıklardan nefret eden kimse Allah için buğzetmiş olur. Kim Allah için buğzederse Allah da onun için buğzeder. Adalet dört şubedir. Birincisi dinde enyüksek mertebeye ulaşmaktır. İkincisi bütün dinî ilimleri bilmektir. Üçüncüsü şer’̂̀ hükümlerde doğru karar vermek, dördüncüsü ise bütün zorluklara karşı sabretmektir. Kim sabrederse insanlar arasında rahat yaşar. ${ }^{75}$ 9) "Güzel ahlâk dinin yarısıdır"76 10) "İslâm güzel ahlaktır."77 gibi gerçek manaları olan hadisler varken kelâmcılar şu hadisleri tahrif edip mecazî manalara taşıdılar. Hadislerin ve âyetlerin delaletlerine riâyet edersek Allah'in katında itibar olunan iman, akıldan, güzel ahlaktan, hayır ve hasenattan, doğru itikatlardan

\footnotetext{
68 Buhârî, Îmân" 2; Müslim, "Îmân" 57 (35), 58 (35).

69 Ahmed b. Hanbel, Müsnedü'l-İmâm Ahmed bin Hanbel, thk. Şu'ayb el-Arnaût vdğ., I-L, (Beyrut: Müessesetü'rRisâle, 1995-2001), XXXII, 177-8, XXXVII, 389-90

70 Hadis kitaplarında bu hadisin kaynağı tespit edilememiştir.

${ }^{71}$ Deylemî, el-Firdevs bi-me'sûri'l-hitâb, thk. Saîd b. Besyûnî Zağlûl, I-VI, (Beyrut: Dâru'l-Kütübi'l-İlmiyye,1986), I:111; Müttakî el-Hindî, Ali b. Hüsâmüddîn, Kenzü'l-Ummâl fì Süneni'l-Akvâl ve'l-Ef'âl, tsh. Bekrî Hayyânî-Saffet es-Sekkâ, I-XVI, (Beyrut: Müessesetü'r-Risâle, 1985), 1: 36.

72 Buhârî, "Îmân" 3; "Rikâk" 26; Müslim, "Îmân" 64-65-66.

${ }^{73}$ Taberânî, El-Mu'cemü'l-Evsat, thk. Târık b. Avdillah b. İbrahim el-Hüseynî, I-X, (Kahire: Dâru'l-Harameyn, 1995), 8: 336.

74 Buhârî̀, "Îmân" 6; Müslim, "Îmân" 71-72 (45).

${ }^{75}$ Müttakî el-Hindî, Kenzü'l-ummâl, 1: 286-7; Ayrıca bkz. Münâvî, Feyzü'l-kadîr şerhu'l-Câmi'i's-sağîr, I-VI, (Beyrut: Dâru'l-Ma'rife, 1972), 6: 63-4.

76 Süyûtî, el-Câmi'u's-Sağîr fì Ehâdîsi'l-Beşîri'n-Nezîr, I-II, (Beyrut: Dâru'l-Kütübi'l-İlmiyye, 2004), I:184; Aclûnî, Keşfü'l-hafâ ve müzîlü'l-ilbâs, I-II, (Kahire: Mektebetü'l-Kudsî, 1351), 1: 58-9.

77 Müttakî el-Hindî, Kenzü'l-Ummâl, 3: 17.
} 
ibaret olur. Amelde eseri olmayan itikadın, Allah katında da itibarı yoktur. Dil ile söylenen söz, kalpte gizlenmiş iman, amele yakın olmadıkça geçerliliği yoktur.

Ameli imanın dişında tutup, imanı yalnız dil ile ikrardan ibaret saymak, mantık felsefesi itibarıyla kelâmcılara göre geçerli olabilse de insanın edebine, istikametine, bütün maslahatlarına esas olmak yönüyle kutsaldır. İmandan amel çıkarılamaz. İnsanın yalnız şahsına nispetle iman, güzel amelden ve güzel ahlaktan ibarettir. Fakat milletin ve devletin genel işlerine oranla iman; adaletten, emanetten hakkaniyet gibi şeylerden ibarettir. Bir insanın hayatını, fesadı, zulmü ve zararları dikkatimizi çekerken kalbinde gizlenmiş imanın, manasız bir şekilde dil ile ikrarının önemi kalmaz.

İdare ve siyaset işlerinde iman ve küfür yoktur, sadece adalet ve zulüm vardır. Genel işlerde itibar kılınan iman, Allah katında adalet ile aynı anlama gelmektedir. Küfür de zulüm ile aynı manadadır. Kur'an'da devlet ve millet yararına hükümler vardır. İslâm'ın en çok münasebeti de bunlarla ilgilidir. Allah'ın hikmetine en çok uyan siyasete gore zulmü küfürden, imanı adaletten ayırmak yanlıştır. Böyle bir yanlışı zalimler ve zorbalar heva ve heveslerine en uygun bir hile olarak bulmuşlardır. Dolayısıyla bu hile satılmıs hainler tarafından ihdas edilmiş bir bidattır.

İslâm kanunları, umumî işleri, kalbin imanına dilin ikrarına tesis etmemiş, belki adalet ve maslahat esasları üzerine kurulmuştur. Kalp ile tasdik, dil ile ikrar hiçbir şekilde esas olamaz. Eğer din adalet üzerine tesis edilmez ise veya biri diğerine müradif gibi olmaz ise öyle din hainlerin ve zalimlerin hevalarına alet olur. Hakk yolunda olanlara her yönüyle zarar verir.

Kelâm mezhepleri, iman1, bozuk itikattan, kuru bir ikrardan ibaret sayı, ameli imanın dışında tutarken; hilafet tartışmalarına, kavmiyet taassuplarına bina edilmiş ŞiîlikSünnîlik ihtilaflarında imanı neden dışında tutmadılar? En azından İslâm dünyası, kan davası güden mezheplere, biri diğerine lanet okuyan fırkalara bölünmüş olmazdı. İslâm akidesinin diyanetle hiçbir münasebeti yoktu. Beyhude şeylerden hiç olmazsa uzak kalırd1."78

\section{3. 3. İman-III ${ }^{79}$}

Bölümün başından buraya kadar yazılan mülahazalara göre, iman hususunda kelâm mezheplerine muhalefet etmem nedeniyle özür dilerim. Buna göre, İslâm dininde iman, doğru inançlardan, güzel amellerden, güzel ahlaktan, hayır ve hasenattan ibarettir. Din, zamana ve mekana göre insanın sorumluluğunda olan vazifeyi layıkıyla yerine getirmekten ibarettir.

İman, İslâm'ın umumi bir şiarı olması yönüyle "Lâilâhe İllallah Muhammedün Resûlullah" kelime-i tevhidini samimi bir dille söylemekten ibarettir. Şu mübarek kelimenin

\footnotetext{
78 Mûsâ Cârullah, "İman-II", 38-42.

${ }^{79}$ Mûsâ Cârullah, “İman-III”, İslâm Dünyası, 1/4, (17 Cemâziyelevvel, 1329-1331), 52-54.
} 
kapsadığı manayı kabul eden insanların her biri mü'mindir. Bundan sonra Eş'arîlik, Mu’tezilelik, Şî̂lik ve Sünnîlik gibi ihtilaflara itibar etmek kesinlikle haramdır. "Dinî doğru tutun ve onda tefrikaya düşmeyin (Şûrâ, 42/13)". "Gerçek şu ki, dinlerini parça parça edip guruplara ayıranlarla artık senin hiçbir ilişkin yoktur. (En'âm, 6/159)”

İslâm akîdesine mezhep ihtilaflarını sokmak gibi bir cinâyet İslâm tarihinde yoktur. Hilafet kavgaları, Alevîlik, Emevîlik düşmanlıkları gibi siyasî ihtilaflardan uzak olarak kelâm mezhepleri tesis etmek, kelâm kitapları yazmak gibi hiyanet veya ahmaklık İslâm aleminde bulunmamıştır. İslâmiyette mezhep birdir. Kelime-i Tevhidi, İslâm şiarını kabul eden her bir insan mü'mindir. Tevbe suresinde "Kul in kâne" âyet-i kerimesinin hükmüne göre şu iman en büyük yakınlıktır.

İman, insanla yaratıcısı arasında kutsal bir bağdır. Burada yaşayan ve yaşamayan mezhepler hiçbir şekilde muteber değildir. İman ilahî bir talimdir demek basit olur. Dolayısıyla felsefî izahlara fennî 1stılahlara ihtiyaç yoktur.

İman, insanın Allah'ın dergahına sığınmasıdır. İnsan hiçbir dakikada, hiçbir durumda oradan kovulamaz. Allah'in rahmet kalpıları her zaman açıktır. Oralarda muhafızlar bulunmazlar. İhtiyaç sahiplerinde, çaresiz miskinlerde, zarurî durumlarında her kul, her vakit rahmet dergahlarında elbette kabul edilir.

"Peki darda kalan kendisine yalvardığı zaman imdadına yetişen, sıkıntısını gideren ve sizi yeryüzünün yöneticileri yapan kim?” (Neml, 27/62) âyetinde zorda kalanların dualarını kabul etmek övülerek böyle anlatılmıştır. Şu âyette "Bizim dayanılmaz azabımızı gördükleri zaman, (bu itiraf ve) imanları kendilerine hiçbir yarar vermeyecek" (Mü'min, 40/85) demek, görülen azabı kaldırmak faydasız oldu demek olsa gerektir. Buna "Hiçbir şehir ahalisi yoktur ki, (yeis halinde) imân etmiş olsun da bu imânı ona faide versin. Yûnus kavmi ise müstesna" (Yûnus, 10/98) âyeti kerimesindeki istisna ve "iman ettikleri zaman dünya hayatında onlardan aşağılatıcı azabı kaldırdık ve onları belli bir zamana kadar yararlandırdık" (Yûnus, 10/98) âyet-i kerimesindeki beyan delalet eder.

Yani azabı gördükten sonra iman edip te imanı fayda veren bir işaret yoktur. Sadece Yunus Peygamber'in kavmi, iman ettikten sonra biz onlardan azabı kaldırdık. Burada yeis halinde bir imanın fayda verip vermeyeceği yönü dünya azabını kaldırıp kaldırmamak hususuna munhasır kalmıştır. Bu âyetler ile maksadımı delillendirirken Nisa suresindeki 17-18. âyeti kerimelerinden habersiz değildim. "Yeis halinde iman makbul değildir" ifadesinde Allah'ın geniş rahmetini daraltmak şaibesi vardır. Binaen aleyh ben, "Yeis halinde iman makbul olur" inancindayım.

Bizim gibi aciz bir miskin, zor zamanlarda ve dehşet anlarında Rabbinin rahmet kapılarına sığınırken, geride durup "Ey sen, ben susayan o adama rahmet deryalarından bir damla verme! diye bağırmaya utanırım...." 
İmanın rahmeti ilahi dergahında şartsız makbul olacağı hakkında benim görüşüm şudur: İmanda resmiyet yoktur. İmanın mezhebi de yoktur. "Muhakkak ki Allah'n üç yüz onbeş şeriatı vardır. Aziz ve Celîl olan Cenâb-1 Hak: "Kullarımdan, bana ortak koşmayan her kim bunlardan bir tânesini yerine getirse mutlaka cennete koyarım" der. Bu hadis; Enes, Osman ve Ebû Saîd gibi sahabeden, birçok hadis kitaplarında, büyük imamlar tarafından rivâyet olunmuştur ki kabul dergahlarının genişliği hakkında söylenmiş olsa gerek.

Bundan sonra imanda, özellikle de İslâm inancında önem verilen en değerli şey, dünyada insanın mutluluğunu sağlamaktır. İslâm inancının en büyük önemi, diğer akidelere nispetle ulviyeti burada bulmak gerekir. İman, dünyada insanın temizliğine, doğruluğuna, emanete sahip çıkmasına, çalışmasına, refahına, izzetine, kurtuluşuna esas olursa işte öyle bir iman İslâm dininin istediği iman olmuş olur.

Ahiret mutluluğu, bugünkü mutluluğun semeresidir, sonucudur veya lahikasıdır. Mutluluğu dervişlikte, miskinlikte, rahatı yoklukta aramak Hindistan fakirlerinin, Brahmanlarının felsefesidir.

Her dinin en büyük gayesi mabuduna benzemektir. Bizim mabudumuz, putperestlerin mabudu gibi cansız put, ruhsuz resim değildir. Bizim mabudumuz; hayy, âlim, her şeye gücü yeten, aziz, büyük, zengin, cömert, her şeyin sahibi, seyyid, emreden, hakîm, alemlerin rabbı Allah’tır. Bizde ilim, kudret, sanaat, izzet, büyüklük, varlık gibi özellikler bulmak, dinimiz ve imanımızın gereklerindendir. O kemalatın her biri dinimizin gayesi, şeriatımızın emridir.

Dini dil ile ikrar, kalp ile tasdik etmekle kısaltmak acizlik, dervişlik felsefesidir. Şu dünyada saadeti, ecnebilere layık görüp bugünkü saadetten ümit kesmek, bize hariçten sirâyet etmiş veya hile yoluyla aşılanmış gâyet helak edici bir hastalıktır. İslâmiyetin en büyük rükünleri şunlardır: Sahih bir inanç, Allah’ı tazim, insaniyet ve izzet. "Halbuki kuvvet ve üstünlük Allah'ın, Rasûlünün ve Mü'minlerindir (Münafikûn, 63/8).

Benim nazarımda İslâmiyet, imanı şu günkü saadetten kendi ümidimizi kesip, gelecek saadetten diğerlerinin ümidlerini kesmek esaslarına mebni değildir. İslâmiyet imanı her iki saadeti birleştirirse Allahın rahmetleri geniş olarak kalırsa daha güzel olur. Ben dünyada izzeti, İslâm saadetini, imanına ahlakına daha ziyade uygun ve gerekli görüp, İslâmiyetin istikbaline iman ederim.

Avrupa'daki gelişmelere özgürlük gözüyle ve kendi halimize teessüf gözüyle bakıp geleceğimizden ümidi kesen mütefekkirlerin fikirlerine iştirak edemem... Dervişlik, zahitlik tesiriyle şu fani dünyada insaniyetin de İslâmiyetin de geleceğinden ümit kesmiş kötü beyinlerin görüşlerini tasvîp etmek münkün değildir... İnancıma göre İslâm’in da Müslümanların da istikballeri vardır. Kur'an-1 Kerîm'in ilahi müjdeleyicisi şudur: "Ki o, kendi peygamberlerini hidâyetle ve hak olan din ile, diğer bütün dinlere karşı üstün kılmak 
için gönderdi (Fetih, 48/289). Kur'an'da sayılı âyetlerde gelen işte şu ilahi müjde bugün araştırılmamış ise yarın elbette araştırılır..." 80

\section{Sonuç ve Değerlendirme}

Mûsâ Cârullah, İslâm Dünyası dergisinde "İman" başlığıyla yayımlanan makalelerinde Ehl-i Sünnet ulemasının iman ile ameli ayrı ayrı değerlendirmeleri neticesinde İslâm toplumunun pek çok zararlar gördügüne işaret etmiş ve bu bağlamda gelenekçi çizgide yer alan ulemaya eleştiriler yöneltmiştir. Dünya ve ahiret kurtuluşu için imanın önemine dikkat çekerek insanın imanına küçümseyerek bakan ve İslâm itikadına sonradan giren bâtıl inançları imanın bölümleri gibi gösteren itikadî mezhepleri tenkit etmiştir.

İslâm'ın köhne düşüncelerin esiri olamayacağına inanan Mûsâ Cârullah, makalelerinde sürekli Kur'an'ın her çağın düşüncelerine cevap verdiğine dikkat çekmiş ve gericiliğe karşı olduğunu vurgulamıştır. İslâm coğrafyasında yaşayan Müslümanların gaflet uykusundan uyanmaları için onlara kurtuluş reçeteleri sunmuş ve kurtuluşun asıl kaynağının imanın gücünde olduğuna işaret etmiştir. Amel, itikat ve ahlakın imanın temen taşları olduğunu, insanların yaptıkları şeylerin devletin ve milletin faydasına olduğu sürece imanın derecelerinin de artabileceğini belirtmiştir.

Makalelerinde âyet ve hadisleri delil göstererek ameli imandan ayırmanın yanlış olduğunu vurgulamış, kurtuluş reçetesi olarak görülen imanın kalp ile tasdik, dil ile ikrardan ibaret sayılıp da akıl, ilim, güzel ahlak, sâlih amel gibi insanî değerlerin her birinin imandan çıkarılmasıyla yapılan yanlışlığa dikkat çekmiştir. Ehl-i Sünnet inancında benimsenen dil ile ikrar ve kalp ile tasdikten ibaret olan iman anlayışını eleştirmiştir.

Makalelerde "amel imanın dışındadır, artar" yerine "amel imanın delilidir" vurgusu yapılarak amel-iman ayrımına gidilmemiş ve Ehl-i Sünnet'in amel-iman ayrımının yanlışlığından bahsedilmiştir. Dolayısıyla İman ile ameli ayrı ayrı değerlendiren Ehl-i Sünnet uleması tenkit edilmiştir. İslâm dünyasının durumu ile itikadî mezhepler arasında çok büyük bağlantıların olduğuna işaret edilmiş, İslâm dünyasında yaşanan siyasî olayların ya itikadî mezheplerden kaynaklandığı ya da itikadî mezheplerin siyasî olaylara göre tertip edildiği belirtilmiştir. Özellikle de itikadî mezheplerden Eş’arîlerin ilkeleri, ahlakın ve siyasetin bozulmasına en uygun şekilde konulmuştur. Sünnîlik ile Şiîlik gibi mezhepler arasındaki ihtilaflar, düşmanlıklar, lanetleşmeler ayrılık esasları üzerine tesis edilmiştir. İslâm âleminde yaşanan siyasî olayların gerçek nedenleri Müslümanların itikadlarına bağlanmıştır. İnsanın itikadı; iradesine, ahlakına ve bütün hareketlerine etki etmesi nedeniyle siyasî olayların gerçek nedenlerinin itikadî mezheplerde aranması gerektiğine işaret edilmiştir.

Mûsâ Cârullah'ın, mezhepler arasındaki ihtilafı ortadan kaldırmayı, kelâmcıların ortaya koyduğu Ehl-i Sünnet anlayışını, dar çerçevesinden kurtarıp Kur'an ve Sünneti

${ }^{80}$ Mûsâ Cârullah, “İman-III”, 52-54. 
merkeze alan oldukça geniş bir alana taşımaya çalıştığı anlaşılmaktadır. İslâm dünyasının gerilemesinde; mezheçiliğin, ictihat kurumunun işlevselliğini yitirmesi, amelin imana dahil edilmeyerek ayrı değerlendirilmesi, yanlış tevekkül anlayışı, taklit ile birlikte Müslümanları atâlete sevkeden yanlış "kaza" ve "kader" anlayışının etkili olduğunu vurguladığ1 görülmüştür. Mûsâ Cârullah'in, İslâmı mezheplerden üstün tuttuğunu, genellikle mezhepler ile ilgili eleştirilerinde ölçülü bir metot kullandığını ve aklı hapseden mezhep taassubuna şiddetle karşı çıktığını söylemek mümkündür. 


\section{Kaynaklar}

Abdülvahhab. "Ak1l", İslâm Dünyası, 2, 18 Rebîülâhir 1329-1331/14 Mart 1913.

Abdürreşid İbrahim. "Acı Hakikatler İtiraf Olunmadıkça Islâh Mümkün Olamaz". İslâm Dünyası, 1, 6 Rebîülâhir 1329-1331/2 Mart 1913.

Abdürreşid İbrahim. "Ed-Dîn ve'l-Îmân Kavl ve Amel”, İslâm Dünyası, 2/1, İstanbul 13301332.

Aclûnî, Ebü'l-Fidâ İsmâil b. Muhammed b. Abdülhâdî. Keşfü'l-hafâ ve müzîlüllilbâs. I-II, Kahire: Mektebetü'l-Kudsî, 1351.

Ahmed b. Hanbel. Müsnedü'l-İmâm Ahmed bin Hanbel. thk. Şu'ayb el-Arnaût vdğ., I-L, Beyrut: Müessesetü'r-Risâle, 1995-2001.

Ak, Ahmed. "Ebül-Muîn en-Nesefíye Göre İman-Amel İlişkisi”. Dinî Araştırmalar, 8/24, (2006): 245-252.

Akseki, Ahmed Hamdi. İslâm Dîni. Ankara 1969.

Balaban, Mustafa Rahmi, "Mûsâ Cârullah (1875-1949), Hayat1, Felsefesinden Birkaç Çizgi, Eserleri”, İslâm Tetkikleri Enstitüsü Dergisi, 1/1-4, (1954):173-178.

Bigiyef, Mûsâ Cârullah. "İman-I". İslâm Dünyast, 1/2, (18 Rebîulâhir, 1329-1331): 21-24.

Bigiyef, Mûsâ Cârullah. "İman-II". İslâm Dünyası, 1/3, (3 Cemaziyelevvel, 1329-1331): 3842.

Bigiyef, Mûsâ Cârullah. "İman-III". İslâm Dünyası, 1/4, (17 Cemaziyelevvel, 1329-1331): 5254.

Bigiyef, Mûsâ Cârullah. Büyük Mevzularda Ufak Fikirler. Petersburg 1914.

Bigiyef, Mûsâ Cârullah. El-Lüzûmiyât Tercümesi. Kazan 1907.

Bigiyef, Mûsâ Cârullah. Halk Nazarına Bir Niçe Mesele. nşr. Muhammed Efendi Maksudof Kazan 1912.

Bigiyef, Mûsâ Cârullah. Tarihin Unutulmuş Sahifeleri. Berlin: 1933.

Bigiyef, Mûsâ Cârullah. Uzun Günlerde Oruç. sad. Yusuf Uralgiray, Ankara: Kazan Türkleri Kültür ve yardımlaşma Derneği Yayınları, 1975.

Buhârî, Ebû Abdullah Muhammed b. İsmâil Sahîhu'l-Buhârî, thk. Mustafa Dîb el-Buğâ, IVII, Beyrut: Dâru İbn Kesîr-Yemâme, 1993.

Çam, Süleyman. Osmanlı'dan Cumhuriyet'e Geçiş Sürecinde Mezhep Tartışmalar. Adana: Çukurova Üniversitesi, Sosyal Bilimler Enstitüsü, Doktora Tezi, 2019.

Deylemî, Ebû Şücâ' Şîrûye b. Şehredâr el-Firdevs bi-me'sûri'l-hitâb, thk. Saîd b. Besyûnî Zağlûl, I-VI, Beyrut: Dâru'l-Kütübi'l-ìlmiyye, 1986. 
Ebû Hanîfe, İmâm-1 Âzam. Fıkh-ı Ekber Şerhi, haz. İsmail Kaya, İstanbul: Medve Yayınları, 1984.

El-Ofi, Mehmed Emin b. Hasan b. Hüseyin. İman Risâlesi (Ehl-i Sünnet Mezhebi Üzere İmanı Beyan). İstanbul 1317.

El-Pezdevî, Ebü'l-Yüsr Muhammed b. Muhammed b. el-Hüseyn b. Abdilkerîm. Ehl-i Sünnet Akâidi. trc. Şerafeddin Gölcük, İstanbul: Kayıhan Yayınları, 2017.

Fehmi, Hasan. Risâle-i İman. Üsküp: Kosova Vilâyet Matbaası, t.y.

Gafarov, Raim. Mûsâ Cârullah Bigiyef'in Kader Hakkındaki Görüşü, Bursa: Uludağ Üniversitesi, Sosyal Bilimler Üniversitesi, Yüksek Lisans Tezi, 2009.

Görmez, Mehmet. Mûsâ Cârullah Bigiyef. Ankara: TDV Yayınları, 1994.

Kalberdiev, Abdilaziz. Mûsâ Carullah Bigiyefin Kelâmî Görüşleri, Ankara: Ankara Üniversitesi, Sosyal Bilimler Enstitüsü, Yüksek Lisans Tezi, 2004.

Kanlıdere, Ahmet. "Mûsâ Cârullah'in Eserleri Hakkında Bilgiler, Ölümünün 50. Yıldönümünde Musa Carullah Bigiyef (1875-1949”). I. uluslararası Mûsâ Cârullah Bigiyef Sempozyumu, Ankara: TDV Yayınları, 2002.

Kanlıdere, Ahmet. "Mûsâ Cârullah". Türkiye Diyanet Vakfı İslâm Ansiklopedisi, 31: 214-216. İstanbul: TDV Yayınlar1, 2006.

Kanlıdere, Ahmet. Kadimle Cedit Arasında Mûsâ Cârullah: Hayatı-Fikirleri-Eserleri. İstanbul: Dergâh Yayınları, 2005.

Kaplan, İbrahim, Kelâm III, edt. İsmail Ş1k-Nail Karagöz, Ankara: Gece Kitaplığı, 2017.

Keskioğlu, Osman, "Mûsâ Cârullah (1875-1949), Hayat1, Görüşleri ve Eserleri", Ankara Üniversitesi İlahiyat Fakültesi Dergisi,1964, 12: 63-73.

Kırşehiri, Ömer, "Hakikat-ı İman ve İslâm", Cerîde-i Sûfiyye, 1/ 1, 6 Mart 1325.

Kırşehiri, Ömer, "Hakikat-i İman ve İslâm”, Cerîde-i Sûfiyye, 1/2, 13 Mart 1325.

Kırşehiri, Ömer, "Hakikat-i İman ve İslâm”, Cerîde-i Sûfiyye, 1/6-4, 8 Teşrinievvel 1327.

Kurban, Nur Ahmet, "Mûsâ Cârullâh'nn (1875-1948) Yaptığ1 Tatarca Kur'ân Tercümesi Üzerine Bir Değerlendirme”. Türkoloji Araştırmaları, 11/17, (2016): 467-486.

Maraş, İbrahim. Türk Dünyasında Dinî Yenileşme (1850-1915). İstanbul: Ötüken Yayınları, 2002.

Mert, Hamdi. "Mûsâ Cârullah Bigiyef-Hayat1, Mücadelesi, Fikirleri-". Bilig: Türk Dünyası Sosyal Bilimler Dergisi, 8 (1999): 125-138.

Münâvî, Muhammed Abdürraûf b. Tâcil'ârifîn. Feyzü'l-kadîr şerhu'l-Câmi'i's-sağîr, I-VI, Beyrut: Dâru'l-Ma'rife, 1972. 
Müslim, Ebü'l-Hüseyin Müslim b. el-Haccâc, Sahîhu Müslim, nşr. Muhammed Fuâd Abdülbâki, I-V, Kahire: Dâru İhyâi'l-Kütübi'l-Arabiyye, 1991.

Müttakî el-Hindî, Ali b. Hüsâmüddîn. Kenzü'l-Ummâl fî Süneni'l-Akvâl ve’l-Ef'âl. tsh. Bekrî Hayyânî-Saffet es-Sekkâ, I-XVI, Beyrut: Müessesetü'r-Risâle, 1985.

Naki, H. “İman-İnsan”. Medrese İtikadlar, 4, 27 May1s 1329.

Özbek, Nadir. "Abdürreşid İbrahim İslâmcı Bir Eylem Adamı”, Toplumsal Tarih, 4/19, (1995). 7-12.

Rıfat. Delâilül-İkan fì Beyan-ı Kavâidi'l-İmân. Dersaadet: Mahmut Bey Matbaası, 1316.

Savaş, Akif. Kelâmın Yenileşme Sürecinde Mûsâ Cârullah Bigiyef. İzmir: Dokuz Eylül Üniversitesi, Sosyal Bilimler Enstitüsü, Yüksek Lisans Tezi, 2010.

Suyargulov, Rifat. "Mûsâ Cârullah'ın İlahi Rahmetin Genişliği Hakkındaki Düşüncesinin Değerlendirilmesi”. Dinî Araştırmalar, 20/52 (2017): 201-222.

Süyûtî, Ebü'l-Fazl Abdurrahman b. Ebû Bekr. El-Câmi'u's-sağîr fì ehâdîsi'l-beşîri’n-nezîr, I-II. Beyrut: Dâru'l-Kütübi'l-İlmiyye, 2004.

Taberânî, Ebü'l-Kâsım Süleyman b. Ahmed. El-Mu'cemü'l-Evsat, thk. Târık b. Avdillah b. Muhammed-Abdülmuhsin b. İbrahim el-Hüseynî, I-X, Kahire: Dâru'l-Harameyn, 1995. 


\title{
MÛSÂ CÂRULLAH BIGIYEF MASTER AND HIS ARTICLE TITLED FAITH
}

\begin{abstract}
In this study, the life, works and some theological views of Musa Carullah Bigief Master, one of the Tatar scholars, who lived in the last period of the Ottoman Empire. In addition, his article "Faith", which he wrote in the context of the relationship between faith and deed, has been evaluated by simplifying it with the idea that he can contribute to the History of Kalam and Sects. Theological issues such as the relationship between faith and deeds are discussed in different periods of the Islamic world. The relationship between faith and deeds came to the agend a for the first time after the war of Siffin, when the Kharijites redefined the faith and rejected those who committed great sin. In describing the faith, the Kharians included all deeds in it, thus ruling that the sinner would be a heretic even if the sin was small. This issue was also discussed by the Islamic scholars in the late Ottoman period. The ulama in the traditionalist line considered faith as separate deeds, but Musa Carullah, who was from the Tatar ulema and also in the modernist and reformist line, didn't made a distinction between faith and deeds. He pointed out some inaccuracies in the separation of faith and deeds of Ahl al-Sunnah. He put forward his views on this subject and his criticisms of the ulema in the traditionalist line.

Musa Carullah pointed out that there are great connections between the situation of the Islamic world and the religious sects. He pointed out that the political events in the Islamic world were either caused by the Islamic sects or that the religious sects were organized according to political events. Especially Ash'ari of the principles he put forward lay the groundwork for the deterioration of morality and politics, It is of the opinion that conflicts between sects such as Sunni and Shiite cause separations and even hostility among Muslims. The real reasons of the political events in the Islamic world have been attributed to the cult of the Muslims. The creed of man; he pointed out that the real causes of political events should be sought in Islamic sects because of their influence on their will, morality and all their movements. He tried to eliminate the conflict between the sects and to move the understanding of the Ahlal-Sunnah, put forward by the theologians, from its narrow frame and to carry it to a very large area that takes the Quran and the Sunnah into the center. In the decline of the Islamic world, the supporters of the sects take the Quran in a narrow frame by considering the views of their sects, loss of functionality of the case law institution, the evaluation of the deed by not including it in faith, wrong understanding of trust, With the imitation, the wrong understanding of "accident" and "destiny", which led the Muslims to inert, has been effective. Musa Carullah took a critical approach to sects, he did not limit himself to any sect, and he made Islam superior to sects and generally used a measured method in his criticism about sects. Through out his life, he never tried to embrace his own views and strongly opposed to the sectarian body of imprisonment.
\end{abstract}

Keywords: Teology, Musa Carullah, Faith, Action, Cardinal Sin. 